\title{
An International Comparison on the Cultivation of Next-Generation Academics in Education Research ${ }^{1}$
}

\author{
Yu-Fei Liu, ${ }^{\mathrm{a}, *}$ \\ ${ }^{\mathrm{a}}$ Chinese Culture University, Taiwan
}

\begin{abstract}
This paper is comprised of an international comparative study on the cultivation of next-generation academics in education research. The purpose of the comparison was to determine international trends in this field, which will be used to evaluate the status quo in Taiwan. Two periods were used for analyzing the process of cultivation: graduate school and postdoctoral research. The research methods employed include a literature review, stakeholder interviews, and comparative analysis. Because of the emphasis on research universities, the cultivation of next-generation academics has received attention worldwide, but very little has been published on this topic. Although several related policies and strategies have been promoted and implemented in many countries, analyses on academic cultivation lack profound investigation and further discussion, specifically regarding education. Consequently, an empirical study on this field is necessary. Therefore, through a comparative analysis with a focus on Japan, this paper provides a summary of the recent international trends regarding the cultivation of next-generation academics. Moreover, I explore the current issues regarding this topic further by applying Bourdieu's forms of capital theory.
\end{abstract}

\begin{abstract}
Abstrak
Sejak awal tahun 1990, negara-negara seperti Inggris dan Amerika Serikat, serta organisasi multilateral seperti UNESCO dan OECD, telah berupaya meningkatkan kualitas penelitian pendidikan dan menjembatani penelitian dengan kebijakan pendidikan dan sekolah. Penelitian ini difokuskan pada lembaga non-pemerintah atau LSM yang melakukan penelitian bidang pendidikan, dengan harapan dapat memperbaiki model LSM penelitian pendidikan di Taiwan. Untuk mencapai tujuan ini, peneliti terlebih dahulu mengumpulkan banyak kajian literatur tentang LSM penelitian pendidikan, kebijakan penelitian pendidikan, indikator kualitas penelitian pendidikan, dan kebijakan sekolah. Kemudian, penulis menyoroti beberapa permasalahan LSM penelitian pendidikan di delapan negara atau beberapa organisasi internasional, guna menganalisa problematika dan kendala mereka terkait dengan kebijakan penelitian pendidikan, indikator kualitas penelitian pendidikan, dan praktek pendidikan. Pengumpulan data dilakukan melalui studi lapangan dan wawancara mendalam untuk masing-masing negara. Kemudian peneliti membandingkan perkembangan dan model LSM penelitian di dunia, termasuk tren terkini di Taiwan. Melalui serangkaian panel diskusi fokus kelompok, peneliti mengkaji situasi terkini LSM penelitian, kaitannya dengan penelitian pendidikan, kebijakan penelitian pendidikan, indikator kualitas penelitian pendidikan dan praktik pendidikan. Penelitian ini menawarkan beberapa saran dan rencana strategis ke depan untuk pengembangan LSM penelitian pendidikan dan isu penelitian pendidikan di Taiwan.
\end{abstract}

Keywords: Next-Generation Academics, Education Research, Education Research Policy, Education Research Quality, Japan, Taiwan

\section{Introduction}

Internationally, in both developed and developing countries, there is a growing consensus among national policy makers and central educational administrators that research universities are crucial drivers for economic growth and development in science and

*Corresponding author. Address: Chinese Cultural University, Taiwan. Email: liurainfly@ hotmail.com. the humanities, and furthermore, they facilitate improving a country's global competitiveness. As Altbach (2011) indicated, key 
twenty-first century realities for tertiary education worldwide include the massification of enrollment, the role of the private sector and the privatization of public higher education, the ongoing debate concerning public versus private goods in higher education, the rise of Asian countries as academic centers, and, recently, the global economic crisis and its effect on higher education. In this context of higher education, the classification of higher education institutions, such as designating research universities, has gradually become a trend. Altbach (2011) also stressed that research universities stand at the center of the twenty-first century global knowledge economy and serve as flagships for postsecondary education worldwide. Research universities produce a substantial amount of new information that not only leads to critical advances in technology but also contributes, equally as considerably, to a clearer understanding of the human condition through the social sciences and humanities (Altbach and Salmi 2011).

Although the role of the research university is crucial, professors and students, as its constituent elements, are more critical. In other words, professors' diligent efforts to be involved in their research and nurture next-generation academics are essential for the sustainable management of a research university. The governments of numerous countries, especially Japan and Taiwan, have been reviewing education research and attempting to conceive strategies to improve the quality of education research since the 1990s. Most governments are aware that human resources in education research are considerably related with educational policies and practices, and the cultivation of next-generation academics is critical for high-quality education research.

In European countries, with the implementation of the Bologna Process in 1999, issues related to the quantity and quality of higher education and research have garnered considerable attention. In addition, some scholars have recognized the urgent need to establish a Europe-wide organization for young researchers. Consequently, a European network of national organizations was established in 2001 (Eurodoc 2016a). Other organizations, such as the European Council of Doctoral Candidates and Junior Researchers (Eurodoc), have been established for the cultivation of next-generation academics. Moreover, in 2014, Eurodoc signed a memorandum of understanding with the International Consortium of Research Staff Associations (ICoRSA), an organization for fostering collaboration among national associations worldwide, which serves to nurture communities of researchers and provides a global voice for research staff and postdoctoral scholars (ICoRSA 2016). Both organizations have similar visions for the future of the European Research Area, and the role of researchers in it. Their future collaboration is expected to give researchers a greater voice in Europe.

Additionally, in Asian countries such as Japan, education research has become more crucial and influential because of global competition. Moreover, Japanese researchers are widely recognized to maintain international research standards. To maintain the success and high standards of Japanese research, the Japanese government, as well as numerous universities and research agencies such as the Japan Society for Educational Sociology (JSES), have highlighted the potential of next-generation academics in education research; furthermore, they believe that training next-generation academics is crucial in ensuring high-quality research (Liu 2015). In the past six years, numerous related policies and strategies have been proposed and implemented.

Furthermore, studying the cultivation of next-generation academics is necessary for analyzing high-quality education research and enables realizing visions of education research in various countries; additionally, it facilitates identifying recent trends in nurturing education research talents in various countries. The cultivation of next-generation academics, specifically concerning science and technology, has received attention worldwide, but has been researched little. Although several related policies and strategies have been promoted and implemented, the analyses lack profound investigation and further discussion, specifically regarding education in the humanities and social sciences. Consequently, an empirical study on the cultivation of next-generation academics regarding the education research field is necessary in Taiwan, Japan, and other countries.

This study is part of a research project (from 1 August 2013 to 31 January 2016) that was financed by the Taiwan Ministry of Science and Technology (MOST). This study is based on an integrated research initiative (1 August 2012 to 31 January 2016) also financed by the Taiwan MOST and entitled "An International Comparison on Education Research Organizations, Research Policies, QualityStandards Construction, and the Relationship between Research and Practices." This study focused on the ability to improve education research mechanisms in Taiwan. Accordingly, the present study provides a comparative analysis on the cultivation of nextgeneration academics in various countries' education research mechanisms, and the main objective countries and international organizations selected by the integrated research initiative that includes the geo-regional countries in Asia (Japan, Taiwan), Europe (United Kingdom, Germany, and France), and United States, Australia, OECD, and the EU. The purpose of the comparison is to identify the international trends in education research to evaluate the status quo in Taiwan.

Moreover, this study analyzed the international trends in the cultivation of next-generation academics with a focus on Japan for the following two reasons. First, according to Figure 1, in 2013, the ratio of Japan's total R\&D expenditure to GDP was 3.75 percent (OECD estimate: 3.45 percent), which is relatively high compared with those of the selected countries. In the past 10 years, the ratios 
of the total R\&D expenditure to GDP in the selected countries have shown an upward trend, except for the United Kingdom and France (Ministry of Education, Culture, Sports, Science and Technology [MEXT] and NISTEP 2015a). Additionally, in 2012, Taiwan was ranked between Japan and Germany; Australia was ranked between Germany and the United States (MEXT and NISTEP 2015b).

Figure 1. Trends in the Ratios of Total R\&D Expenditure to GDP for Each Selected Country

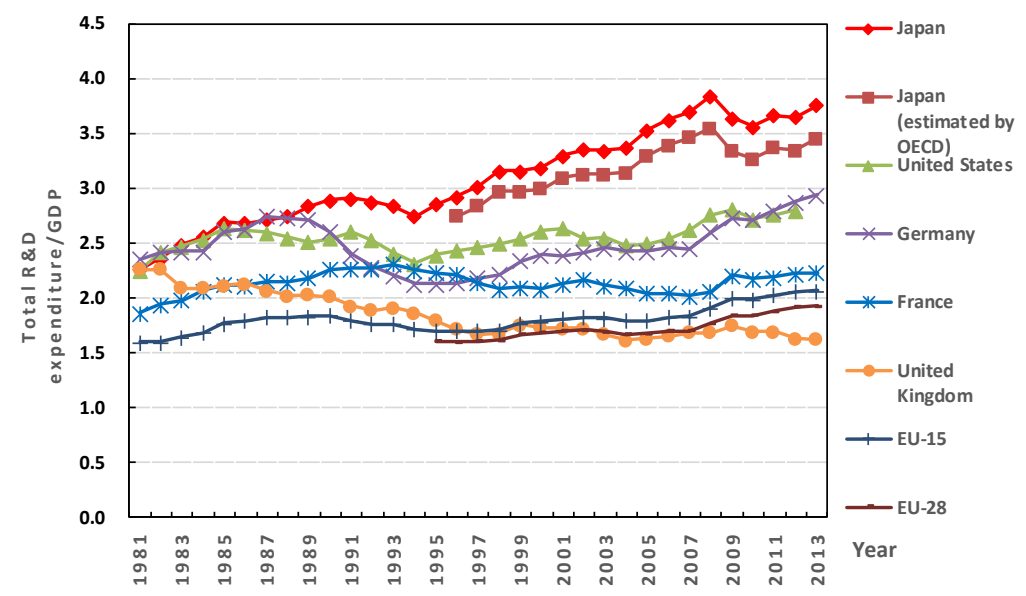

Source: Adapted by the author from MEXT and NISTEP (2015a, p. 1).

Figure 2. Trends in the Number of Researchers per 10,000 Labor Force

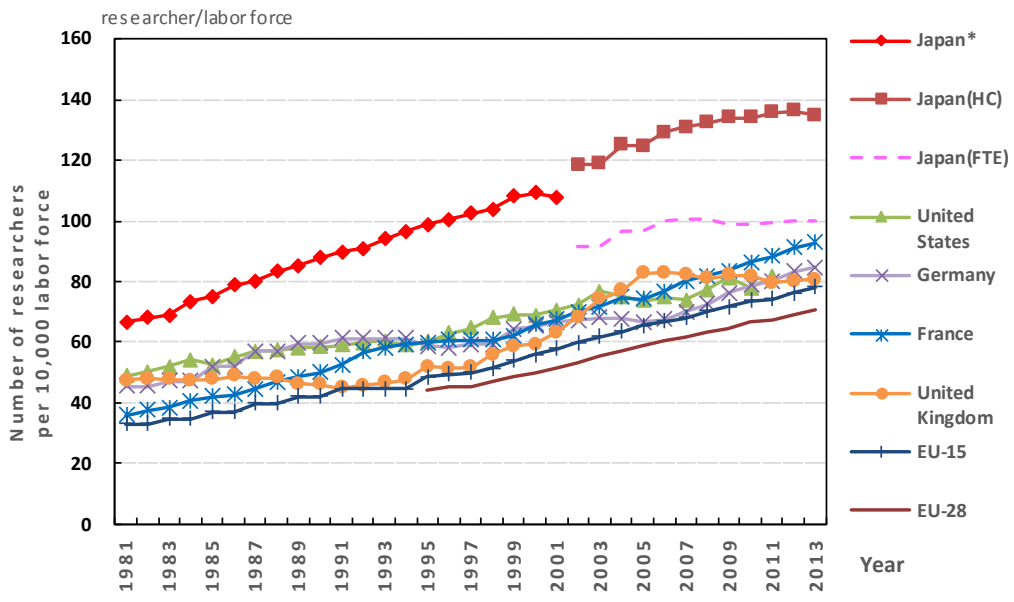

Source: Adapted by the author from MEXT and NISTEP (2015a, p. 63).

Similarly, Figure 2 shows that the number of researchers per ten thousand labor force $\left(\mathrm{FTE}^{2}\right)$ in Japan was the highest among the selected countries in the early 2000s. Additionally, in the past 10 years, most of the selected countries' ratios, except for the United Kingdom, have been on an upward trend (MEXT and NISTEP 2015a). Thus, among the main objective countries, Japan's policies and investments on research, as well as its strategies concerning the cultivation and employment of researchers, are particularly worthy of exploration.

The second reason involves the similarities and relationship between Taiwan and Japan. In Taiwan, after the 2000s, the employment market, including the education research field, exhibited severe problems caused by an imbalance between demand and supply, which resulted from the excessive proliferation of Taiwanese higher education institutions beginning in 1994. Young researchers are facing a severe shortage in research positions; the "stray doctors" (doctors who are unable to find permanent research positions) situation has been highlighted in the media. According to the policy recommendations from the White Paper on Higher Education (MOE, Taiwan, 2001), Taiwan's reform movements regarding higher education have been clearly influenced by Japan's since the 2000s; such movements include national university corporatization, strengthening the role of the research university, focusing on graduate schools, and increasing positions for postdoctoral researchers. Issues of such policies regarding the cultivation of next-generation academics are similar to Japan's. Thus, this topic requires increased attention and a focus on Japan.

On the basis of the results of field studies conducted for the research project, this study employed a literature review, stakeholder interview, and comparative study on the cultivation of next-generation academics in education research to analyze the development of current situations and the process of institutionalization in the main objective countries. Through the comparative analysis that focused specifically on Japan, this paper provides a summary of recent international trends in the cultivation of next-generation academics. Finally, this paper presents a conclusion and provides relevant recommendations.

\section{Methods}

This study employed a literature review, stakeholder interview, and comparative study on the cultivation of next-generation academics in education research in the main objective countries. Two periods were used for analyzing the process of cultivation: graduate school and postdoctoral research. In addition, the study not only explored international trends from a macroscopic global viewpoint but also analyzed each education researcher from a microscopic personal viewpoint. Specifically, to focus on Japan and understand the actual situations regarding the implementations of Japanese policies concerning the cultivation of next-generation academics, this study conducted long-term interviews (December 2012 to October 2015) and researcher surveys (September to October 2015) with Japanese researchers including professors and students at universities, and staff from research agencies. Moreover, case studies of research 
universities in eastern Japan explain how they cultivate the researchers in each period.

The limitation of this comparative study is that in most of the main objective countries, the education field is often classified under the humanities and social sciences, and its data are rarely presented in public statistics. Although data and resources on the humanities and social sciences were required for international comparison from a macroscopic global viewpoint, for convenience, results of the interviews with education researchers were used for microscopic analysis to increase the validity of the findings.

On the basis of the results of the author's previous research paper, "Education Research Organizations, Research Policies, and the Construction of Quality-Standards: The Relationship between Research and Practice in Japan" (May 2015), which was part of the same integrated research initiative, this study extended the followup investigation from August to October 2015. The people who were interviewed and surveyed from December 2012 to October 2015 are described as follows:

1. Two staff members (interviewees A and B) of the National Institute for Educational Policy Research (NIER), Japan's main official education research organization, were interviewed; interviewee A had more than 20 years of work experience at the NIER. Interviewee A was interviewed on 18-19 September 2013, and on 11 September 2015. Interviewee B had approximately six years of work experience at the NIER. Because she had studied in both Japan (until the third year of the doctoral program) and the United Kingdom (doctoral program), she was aware of how policies concerning the cultivation of next-generation academics are implemented in Japan and the United Kingdom. Interviewee B was interviewed on 11 September 2015.

2. Two professors (interviewees $\mathrm{C}$ and $\mathrm{D}$ ), one associate professor (interviewee $\mathrm{E}$ ), two assistant professors (interviewees $\mathrm{F}$ and $\mathrm{G}$ ), and three lecturers (interviewees $\mathrm{H}, \mathrm{I}$, and $\mathrm{J}$ ) at national universities, as well as one lecturer (interviewee $\mathrm{K}$ ) at a private university in eastern Japan were interviewed. All of them hold several memberships to Japanese professional educational societies, such as the JSES. Specifically, interviewee $C$ had ample experience working as a reviewer for Grants-in-Aid for Scientific Research (KAKENHI, described in detail in Section III-1-b). Interviewees E and G-K were "young researchers" (researchers aged 39 and under) in Japan, and interviewees H, I, J, and K were new faculty members at their respective universities. Moreover, because interviewee $\mathrm{H}$ had studied both in Japan (until the third year of the doctoral program) and the United States (doctoral program), she was aware of how policies concerning the cultivation of next-generation academics are implemented in Japan and the United States. In accordance with the time of the interviews, interviewee F was interviewed on 25-31 December 2012, via email. Interviewee C was interviewed on 20 September 2013. Interviewee D was interviewed on 20-22 September 2013, and 9 September 2015. Interviewee $\mathrm{G}$ was interviewed on 9-12 August 2015, and 8 September 2015. Interviewees E, H, I, J, and K were interviewed on 9-12 September 2015.

3. One associate professor (interviewee $\mathrm{L}$ ) at a national university and one associate professor (interviewee $\mathrm{M}$ ) at a private university in western Japan were interviewed. Interviewee L is an expert on the French education system and holds several memberships from Japanese professional educational societies, such as l'Association de recherche sur l'éducation en France. Interviewee $M$ holds several memberships from both Japanese and international professional educational societies, such as the International Sociological Association and the British Sociological Association. Because he is a young researcher, he was aware of the concerns and strategies regarding the cultivation of nextgeneration academics in Japan. Interviewee L was interviewed on 10 September 2015. Interviewee $M$ was interviewed on 1722 September 2013; 11-14 September 2014; 21-27 January 2015, and 21-28 April 2015, via email; and 8-9 September 2015.

4. One postdoctoral researcher (interviewee N) who obtained her $\mathrm{PhD}$ at a national university in eastern Japan and worked at a national university in northern Japan was interviewed on 18-19 September 2013.

5. Three doctoral students (interviewees $\mathrm{O}, \mathrm{P}$, and Q) at a national university in eastern Japan as well as one doctoral student and two master's students (interviewees R, S, and T) at national universities in western and southern Japan were interviewed. Interviewees $\mathrm{O}, \mathrm{P}, \mathrm{Q}$, and $\mathrm{R}$ were interviewed on 20-22 September 2013. Interviewees $\mathrm{O}, \mathrm{S}$, and $\mathrm{T}$ were interviewed on 8-10 September 2015.

6. Four doctoral students (ranging from the second to fifth year of study) (respondents U, V, W, and X) and one master's student (respondent $\mathrm{Y}$ ) at a national research university in eastern Japan were surveyed. They all belonged to the same laboratory group and were under the guidance of the same advisor. All surveys were conducted from September to October 2015.

\section{Cultivation of Next-Generation Academics in Universities and Research Agencies}

On the basis of the results of the stakeholder interviews, this study reviewed relevant literature and comparatively analyzed the meaning and influence of policies and strategies concerning each cultivating period in the main objective countries. 


\section{Graduate Students (Master's and Doctoral Students)}

According to the initial stage of comparisons, most governments and education research organizations of the main objective countries naturally pay substantial attention to the graduate school period, particularly the doctoral program, and many policies or strategies continue to be promoted.

\section{Support From Education Research Organizations (Universities)}

In the context of Asian countries, Japanese research universities aggressively and independently implement various policies and strategies regarding the cultivation of graduate students. According to the results of the interviews, the policies or strategies unique to two specific case studies are summarized below.

Case Study 1. The Tohoku University Graduate School of Education (2016a) has offered a graduate student project-based joint research grant to graduate students (for approximately two to three projects per year) since 2010 . The purpose is to cultivate a comprehensive perspective in graduate students, enhance their comprehensive research capabilities, and encourage them to be professional researchers through collaborative research processes involving planning, implementing, and reporting. The grant (maximum of JP¥200,000) is provided by the dean of the Graduate School of Education through a discretionary fund. After the end of a research period (approximately 10 months), graduate students in the selected projects are required to present their research results at the Research Results Report meeting held in March and subsequently submit their reports.

Case Study 2. The University of Tokyo's Graduate School of Education also offers many fellowships to graduate students, such as the Academic Research Incentives fellowship (a short-term study abroad program), the International Academic Research Support System fellowship, which is provided for writing a foreign language thesis and presenting it at an international conference or contributing it to an overseas journal, and the Doctoral Research Executive Promotion System fellowship (according to the results of the interviews, nearly all doctoral students have a chance to obtain this scholarship), which has been awarded since 2008, and provides JP $¥ 50,000$ per month for up to half a year (University of Tokyo’s Faculty of Education and Graduate School of Education 2013). Additionally, the Organization for Creating Educational Research, established in 2004, is affiliated with the graduate school. The purpose of this new type of research institution, which stimulates and promotes new approaches to education studies unfettered by the framework of traditional research fields, is to identify solutions for increasingly complex and diverse contemporary educational issues beyond the boundaries of existing academic disciplines. In particular, the first priority of the institution is to serve as an agency of academic discourse for graduate students and young researchers across different departments and academic fields (Organization for Creating Educational Research 2016). Additionally, it promotes new education research using alternative approaches by younger generations of scholars and plans and hosts research seminars that are open to the public. Since 2010, the Center for Excellence of School Education, one of the three centers of this research institution, has started to promote a graduate student project-based joint research grant (for approximately five to seven projects per year). Both projects involved in Case Studies 1 and 2 are for fostering graduate students' teamwork, but the difference between them is that the funds for Case 2 are provided by the government and used by professors. Thus, the project in Case 2 is more confined and more directly under professors' direction. However, graduate students at the University of Tokyo's Graduate School of Education, the top university in Japan, clearly have abundant financial resources.

As far as we know, our university has more resources for nurturing researchers, particularly financial resources, than do other universities in Japan. (Interviewees P and Q 2013)

In summary, Japanese universities, with the stereotype of having relatively exclusive reputations, have increasingly recognized the importance of coordination and internationalization for the cultivation of next-generation academics in the past seven years. This is the main reason that this study focused on Japan. However, for other countries such as the United Kingdom, Lee and Boud (2009) indicated that much doctoral study occurs in contexts in which a large laboratory is unavailable and in which students benefit from collaboration with a wide range of postdoctoral researchers and other researchers in a rich and stimulating environment, which is often posited as the ideal "production" model. Furthermore, they argue that there is a widespread recognition in policy and scholarship that doctoral candidates, as apprentice researchers, require more than individual supervision or practical team membership. Consequently, new types of research require different types of researchers - those who can be entrepreneurial, interdisciplinary, and skilled in negotiation and project management as well as in the traditional protocols of a discipline (Lee and Boud 2009). In other words, to face a changing environment in academic research, traditional doctoral education programs, in which doctoral students are often treated as "an extra pair of hands" in a laboratory-based research team or "peripheral participants," should be changed to emphasize teamwork, specifically in communication and cooperation with research team members who have a wide variety of expertise. Such ideas and 
propositions coincide with the aforementioned reform trends identified from the case studies in Japan.

\section{Support From Official Education Research Organizations (Except Universities)}

Financial support systems from official education research organizations function according to two procedures: One involves directly subsidizing an individual graduate student, as does the National Science Foundation Graduate Research Fellowship (since 1952) program in the United States; another involves subsidizing higher education institutions that propose training plans for graduate students (i.e., the proposal is submitted by a faculty member), as did the National Science Foundation's Integrative Graduate Education and Research Traineeship (NSF-IGERT 1997-2013) Program in the United States. In Asian countries, Japan's Grant-in-Aid for Japan Society for the Promotion of Science Fellows (hereinafter referred to as "JSPS fellowships"), introduced in 1985, is a clear example of direct subsidization for an individual graduate student. Prof. Shinya Yamanaka, a Japanese Nobel Prize-winning stem cell researcher, received such a fellowship. Conversely, the NSFIGERT is a specific example of funding university-based projects that alter the traditional paradigm of graduate education by establishing interdisciplinary education and research training programs for doctoral students (Carney et al. 2011). This section mainly discusses these two programs.

As mentioned, Figure 1 shows that, in the past 20 years, the ratio of Japan's total R\&D expenditure to GDP has been at a relatively high level compared with those of the selected countries, and has shown an upward trend.

Figure 3. Trends in the Ratios of Government-Funded R\&D Expenditure in the Selected Countries

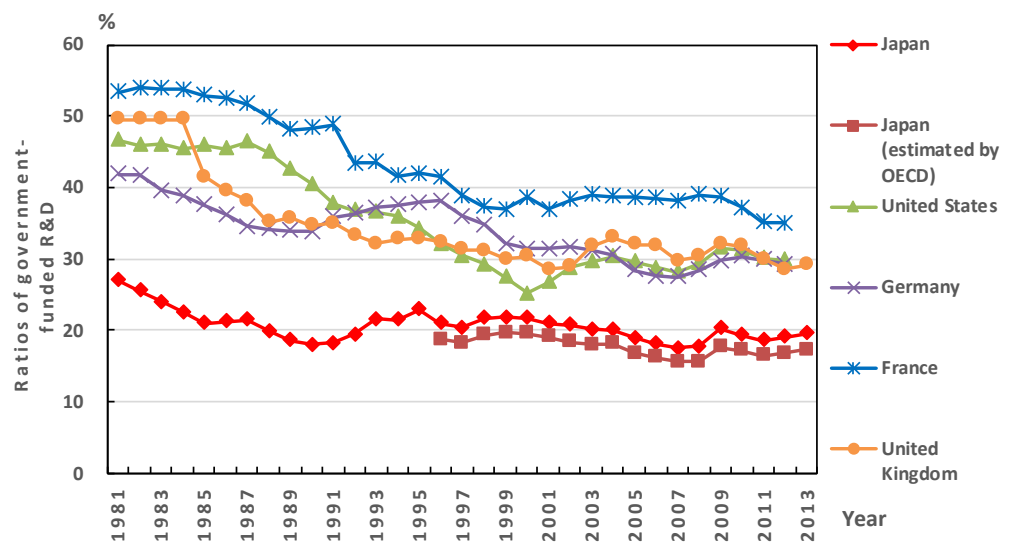

Source: Adapted by the author from MEXT and NISTEP (2015a, p. 28).
However, according to Figure 3, France has the largest percentage of government-funded R\&D expenditure (35.0 percent in 2012). Additionally, in the past 10 years, the percentages of the United States, Germany, and the United Kingdom have been approximate. Japan has the lowest percentage among the seven countries, and in 2013, the percentage of expenditure funded by the government was 19.5 percent (OECD estimate: 17.3 percent). This is because the proportions funded by private universities ( 9.6 percent) and business enterprises (69.6 percent) are higher in Japan, compared with the other selected countries (MEXT and NISTEP 2015a). In other words, the role of Japanese governments in $R \& D$ expenditure is not clear.

In the first half of the 1990s, the Japanese government began to review the role of its investment in basic research (i.e., pure research). Because investments in basic research may not yield expected outcomes, Japan's investment in basic research was very limited until 1995. Compared with the United States and Europe, Japan was far behind in basic research capacity. Moreover, other issues, such as decrepit equipment and lack of research support, emerged at universities and official education research organizations because of the low research investment by the Japanese government (MEXT 2015). Thus, the MEXT, the central educational authority in Japan, has heavily emphasized the necessity of cultivating scientific and technical talent in national development policies, particularly through the Science and Technology Basic Plan, which was introduced in 1996, since the 2011 Tohoku earthquake. Therefore, in the past five years, the MEXT has promoted comprehensive policies addressing primary, secondary, higher, and even lifelong education (MEXT 2011). Similarly, the implementation of policies regarding research funding considerably influences the cultivation of researchers at universities and institutes. Therefore, the MEXT promotes academic research at universities and interuniversity research institutes through enhancing KAKENHI (Liu 2015). Except for certain large-scale national policy- and priority-oriented research projects, which are subsidized and supervised by the MEXT, most KAKENHI research projects are subsidized by the JSPS.

KAKENHI, similar to the funding system of the NSF in the United States, is the largest competitive funding program in Japan. More than 60 percent of Japan's competitive research funding is provided through this program. It is intended to substantially develop all scientific research, from basic research to applied research, in all fields, ranging from humanities and social sciences to natural sciences (JSPS 2016). Moreover, since 2014, the results of KAKENHI research projects have been highly expected to contribute to the country's development and economic growth as well as to obtain an international academic award such as the Nobel Prize. Hence, the KAKENHI JSPS fellowship (up to three years; the original term is "special researcher-DC") is specifically provided to pre- 
and postdoctoral programs for training and securing young researchers at the initial stage of research life. Specifically, since 1991, to encourage excellent master's students to pursue doctoral degrees, JSPS fellowships have been provided to first-year doctoral students.

Consequently, the total number of applicants to JSPS doctoral program fellowships in fiscal year (FY) 1991 dramatically increased by 2.4 times, and has grown markedly every year thereafter. However, the number of selected projects has increased very slowly (more than 1,000 in FY 1996, reaching a peak of 2,116 in FY 2010). This led to a drop in the application-to-funding ratio from 40 percent in FY 1990 to 20.8 percent in FY 1991, which was stable at 19 percent or less for a long period (FY 1997-2006), and decreased to only 10.8 percent in FY 2002. In the past three years, the number of selected projects remained at approximately 2,000, with a rate varying between 21 percent and 25 percent. Application to JSPS doctoral program fellowships remains highly competitive; researchers who have been subsidized by JSPS fellowships are not only well recognized but also greatly benefit from experience in seeking research positions after obtaining their doctorates. According to JSPS survey results (2014), 80 percent of graduates obtained full-time research positions within five years following the completion of fellowships. In other words, JSPS doctoral program fellowships have played a central role in the training and securing of Japan's researchers (JSPS 2014).

In addition to the different types of financial support systems (e.g., JSPS fellowships) that subsidize cost-of-living expenses or provide other stipends and tuition assistance for helping doctoral students concentrate on their research, other types of financial support systems (e.g., NSF-IGERT) designed to improve the quality of graduate education are available. IGERT was the NSF's flagship interdisciplinary training program, educating US PhD scientists and engineers by building on the foundations of their disciplinary education with interdisciplinary training. From 1998 to 2013, 278 IGERT grants were awarded and nearly 6,500 trainees were funded in 41 states and over 100 universities. IGERT awards were approximately US\$3.0-3.2 million for a five-year program, with the major portion of the funds being allocated for $\mathrm{PhD}$ graduate student stipends of US $\$ 30,000$ per year, as well as training expenses (NSF 2016a).

According to the research report "Evaluation of the National Science Foundation's Integrative Graduate Education and Research Traineeship Program (IGERT): Follow-up Study of IGERT Graduates (Final Report)" (Carney et al. 2011), as of 2007, 41 percent of both male and female IGERT trainee PhD graduates in the social sciences (excluding education) completed their degrees within the first seven years of their graduate studies. By the end of their tenth year, 67 percent of female IGERT trainees (54 percent of males) had completed their PhDs; this percentage is higher than the average of 57 percent (both male and female; including education), and the highest value among all disciplines. Moreover, 96 percent of IGERT graduates reported that their IGERT experience positively contributed to their ability to complete their PhDs, and that the traineeship's financial support was the most valuable factor. Furthermore, as of 2007, the employment rate (part- or full-time) for IGERT graduates was 98 percent, and one-third of IGERT graduates (32 percent) were in postdoctoral positions, whereas the remaining two-thirds (68 percent) were employed in the workforce. Nearly half of these employed IGERT graduates (47 percent) were working for universities or colleges, 80 percent of whom were junior faculty members (primarily assistant professors); fewer were in more senior positions as associate professors (7 percent) or full professors ( 1 percent). This report also indicated that even though they were in the early stages of their careers, 4 percent of IGERT graduates in tenure-track faculty positions had already obtained tenure. In other words, for the vast majority of participating trainees, the IGERT experience played a positive role and contributed to both degree completion and employment. However, as McCarthy (2014) indicated, even though the IGERT program enabled many diverse students to engage in more flexible training than they might otherwise have done, no structures remained to continue offering largescale interdisciplinary training after the students graduated. The training program was limited to fully funded students within the IGERT program. To address this capacity building issue, in 2013, the program was reimagined as the National Science Foundation Research Traineeship (NRT) Program (McCarthy 2014). The NRT program, launched in 2014 as the successor to IGERT, retains many of the successful aspects of IGERT, but emphasizes promoting scalable models for graduate student training, which involves including both master's and doctoral students and training for multiple career pathways.

In addition, the NSF's Science of Science and Innovation Policy Doctoral Dissertation Research Improvement Grants (SciSIPDDRIGs) are designed to improve the quality of dissertation research. SciSIP-DDRIGs (estimated number of awards: three to five per fiscal year) provide funds for items not normally supported through the student's US academic institution, enabling doctoral students to undertake major data-gathering projects and conduct field research in settings away from their campus. Outstanding DDRIG proposals specify how creating knowledge advances science and innovation policy (NSF 2016b). However, SciSIPDDRIGs do not intend to cover the full cost of a student's doctoral dissertation research so that the funds may be allocated for valid research expenses (excluding stipends, tuition, textbooks, journals, child care, and allowances for dependents). Moreover, graduate students are not encouraged to submit research proposals, but should 
arrange to serve as research assistants for faculty members (NSF 2014). Thus, SciSIP-DDRIGs are submitted by faculty members on behalf of graduate students.

In summary, official support for doctoral students in the main objective countries has increased in the past 10 years. Similar trends have focused on improving the quality of dissertation research and providing financial support early in the careers of graduate students. Notably, in European countries, the concept of the "industrial PhD," such as France's CIFRE system, the United Kingdom's CASE, and the EU's EID, has begun to receive the attention of Asian countries such as Japan because of the substantial increase in the number of $\mathrm{PhD}$ graduates and their employment difficulties. Since 2012, the MEXT has discussed the possibility of developing a "Japanese industrial PhD." The CIFRE system (introduced in 1981) has two key features: first, doctoral students should be nearly fully supported and funded by the government, and second, their research can be implemented in any academic discipline, even the humanities (13 percent in 2015) and social sciences (12 percent in 2015). Hence, the success rate of the fellowship is high - 90 percent of CIFRE fellows have completed their PhDs (ANRT, 2016a), and 90 percent have obtained employment within 6 months (ANRT 2016b). Moreover, the number of students studying the humanities and social sciences who conduct their research for companies is gradually increasing, and in particular, research on the economy or management is welcomed by both students and companies (Shibata 2010). However, to implement the Japanese industrial $\mathrm{PhD}$, many difficulties must be resolved, such as the difficulty that university teachers experience when required to complete their research according to schedule as required by their respective companies. Additionally, the proposed Japanese industrial $\mathrm{PhD}$ is limited to science and engineering. Therefore, whether it can be applied to education research warrants further exploration.

\section{Support from Nongovernmental Education Research Organiza- tions (Except Universities)}

In Japan, numerous professional educational societies also play influential roles in the cultivation of next-generation academics. Because these societies are mainly composed of scholars at various universities and research institutes, and in order to be familiar with the academic community and establish connections with researchers, graduate students, especially doctoral students, are often required by their supervisors to actively attend and even submit papers to the conferences of these professional educational societies. Regarding support for graduate students, the JSES aims to promote educational sociology and enhance communication for research among its members, especially young researchers. The JSES has approximately 1,500 members and actively conducts various activities. For example, since 2008, the JSES has held the Young Researchers Exchange Meeting every year on the day before the JSES Annual Meeting. The purpose of the Young Researchers Exchange Meeting is to create opportunities for young researchers with limited research experience, including graduate students, to interactively conduct their research outside the context of their universities and laboratories through the free exchange of ideas with other researchers (JSES 2015). Thus, the themes of the meetings are always closely related to problems or difficulties that young researchers may face, and have included "How to obtain a research position" (2013), "Graduate student life and how to proceed with research" (2014), and "Approaches to conducting research/Steps to becoming a researcher" (2015).

Moreover, the JSES has conducted several surveys concerning young researchers' needs and support in recent years, which have included the "Survey of the Research Support Needs of Young Members, Graduate Student Members, and Overseas Student Members" (Hirota 2012). The results of this survey confirmed that educational professional societies play critical roles in the cultivation of next-generation academics, and that the Young Researchers Exchange Meeting is necessary. Such activities are very useful for graduate students and are essential for the cultivation of next-generation academics. The results of the interviews (interviewees $\mathrm{R}, \mathrm{S}$, and $\mathrm{T}$ ) and the surveys (respondents $\mathrm{X}$ and $\mathrm{Y}$ ) indicated a similar opinion. Specifically, junior students (in the second year of a doctoral program and under) reported having interest in these activities - interviewee $\mathrm{R}$ has continued to participate in the annual meeting.

We are very grateful to the JSES for holding such an event for us. On this occasion we not only get to meet a lot of senior researchers but also receive a lot of valuable information and experience. I think few societies are like that in our country.... I will continue to participate next year. I am starting look forward to next year's subject already. (Interviewee R 2013)

Furthermore, the results of the surveys conducted by the JSES clearly revealed young researcher' needs in addition to their various expectations of the JSES's supporting role. Such support, which involves holding various seminars, workshops, and lectures concerning methods of quantitative and qualitative research analysis or writing English papers, can provide opportunities for graduate students to obtain skills and research-related information that cannot be sufficiently provided by their graduate schools. Therefore, since 2013, the JSES has also held the Young Researchers Seminar every year. In the first seminar, Prof. Yoshimasa Kano, the president of the JSES at the time, was eager to promote the cultivation of young 
researchers; he indicated that the JSES, a professional educational society, holds the Young Researchers Seminar for young researchers with research experience from various universities and graduate schools so that they can review the latest research on educational sociology, mutually exchange their research experience, and subsequently attempt to develop a new network of colleagues (JSES 2013).

Additionally, several other Japanese professional educational societies, such as the Japan Comparative Education Society (JCES), the Japan Society for Historical Studies of Education, and the History of Education Thought Society, employ an encouragement system of awards for excellent research (formerly the Hiratsuka Award of the JCES) and offer additional incentives to enhance the research motivations and academic abilities of young scholars (Liu 2015).

Similar to Japan, in the United States and European countries, numerous educational societies and institutes play influential roles in the cultivation of next-generation academics, such as the Council of Graduate Schools in the United States and Eurodoc in Europe. As mentioned, with the implementation of the Bologna Process, issues related to the quantity and quality of higher education and research have garnered considerable attention in European countries. Furthermore, The European Higher Education Area (EHEA) (established in 2010; 47 participating countries), launched on the 10-year anniversary of the Bologna Process, was designed to ensure more comparable, compatible, and coherent systems of higher education in Europe. Moreover, the EHEA considered that "mobility" should be promoted for both students and graduates, as well as for the teaching staff at the outset. Thus, the "Mobility strategy 2020 for the European Higher Education Area" (2012) was proposed. "High quality mobility of students, early stage researchers, teachers and other staff" that "pursues educational goals such as enhancing the competences, knowledge and skills of those involved" was further emphasized. In addition, this strategy suggested that mobility is essential for ensuring high-quality higher education, and that it is crucial for exchange and collaboration with other parts of the world (EHEA 2012). To increase mobility, a specific target was confirmed: at least 20 percent of those graduating in the EHEA in 2020 should complete a training or study period abroad. In other words, the concept of mobility is not limited to EHEA countries; it extends globally (i.e., "global academic mobility"). According to the latest Ministerial Conference (2015), this concept is still being supported. To address the challenges of a continuing economic and social crisis and high levels of unemployment in Europe, the increased mobility of students and staff is expected to foster mutual understanding, and rapid development of knowledge and technology, which affects societies and economies, plays an increasingly critical role in the transformation of higher education and research (EHEA 2015). The EHEA's concept of mobility and reform strategies for enhancing graduate employability have gradually begun to affect Asian countries such as Japan, Taiwan, mainland China, and South Korea. The trend is further discussed in Section IV.

In this context, Eurodoc has played an active role in pertinent Bologna seminars and projects since 2003, and its involvement in the Bologna Process was formally acknowledged in 2007 when the Bologna Process Follow-Up Group granted Eurodoc "partner" status. As an international federation of 32 national organizations consisting of $\mathrm{PhD}$ candidates and early-career researchers, Eurodoc's mission is to represent and consolidate the community of doctoral candidates and junior researchers in Europe in their pursuit of a decent professional life (Eurodoc 2016a). In particular, Eurodoc focuses on improving young researchers' working conditions and advancing the quality of higher education and research in Europe. Hence, Eurodoc Survey I, which concerned the present employment and working conditions of doctoral candidates and junior researchers, was conducted from December 2008 until May 2009 throughout Europe. It analyzed the present situation regarding 7,561 doctoral candidates in 12 countries (Germany, France, Austria, Portugal, Belgium, Hungary, Finland, the Netherlands, Norway, Slovenia, Spain, and Sweden), and provided input for policy recommendations in Europe. Regarding funding, it indicated that the proportion of doctoral students receiving a salary or scholarship varied significantly: 54 percent received funding in Austria, compared with 76 percent in Germany and 82 percent in France (Ateş et al. 2011). When asked whether the amount of funding met living costs, over 50 percent of students in Germany (61 percent) and France (52.3 percent) reported that it did to a high extent. These results may reflect the ratios of government-funded $\mathrm{R} \& \mathrm{D}$ expenditure among the selected countries, which are shown in Figure 3. Overall, national funding systems in Europe are clearly inadequate: a large proportion of doctoral candidates conduct their research without receiving any funding (Eurodoc 2016b).

Furthermore, in the United Kingdom, the Economic and Social Research Council (ESRC), the largest funding organization for research and postgraduate training for economic and social sciences, provides funding for over 600 new postgraduate students each year through its network of 21 Doctoral Training Centres (DTCs; established in 2010). The DTCs are located across the country and consist of 46 institutions, supporting approximately 3,000 PhD students each year with an approximate funding total of GB£40 million (ESRC 2016a). Notably, regarding the distribution of studentships, DTCs emphasize developing the capacity across the various social sciences. Although education (benchmark figure: 8 percent) consistently fell below the target during the first three cohorts, in the most recent cohort (2014/15), recruitment was improved, ultimately meeting the respective target (ESRC 2016b). Furthermore, DTCs are required by the ESRC's sanctions policy to achieve an overall 
4-year submission rate of 60 percent (i.e., the number of funded research students who complete their $\mathrm{PhD}$ within four years).

In summary, both the literature review and results of the interviews indicate a consensus among the main objective countries on the cultivation of next-generation academics: The graduate school period is crucial, specifically for doctoral programs in the past 10 years. Hence, public or private universities as well as official or nongovernmental education research organizations have promoted numerous policies and strategies to improve the quality and quantity of graduate students. A main reason for this trend is closely related to the employment difficulties of graduates, which result from the expansion of higher education institutions and an increase in the number of graduate students, rather than from global competition or national development. These issues are discussed further in the following section.

\section{Postdoctoral Researchers}

Most countries pay substantial attention to the postdoctoral period and have continued to aggressively promote numerous policies and strategies regarding the cultivation of postdoctoral researchers because of the surplus of graduating PhD students. In Japan, policies related to postdoctoral researchers are clearly listed as a critical element of national education reforms. After the implementation of policies (e.g., Focusing on Graduate School Policy) in 1991, emphasis was placed on graduate level programs, and the number of graduate students at national universities in Japan increased from 50,000 in 1990 to 150,000 in 2007. In addition, the number of graduates with a $\mathrm{PhD}$ increased from 6,000 to 16,000 . However, over these 17 years, the number of faculty members at national universities increased from 53,000 in 1990 to 60,000 in 2007, representing an increase of only 7,000 (Japan Science and Technology Policy Seminar Executive Committee 2010). According to the "School Basic Survey," in education research (education and teacher training), the employment rate was 50.3 percent in 2007, but fell to 44.2 percent in 2015 (MEXT 2016).

Figure 4 shows that the total number of $\mathrm{PhDs}$ (per million people) in Japan is far lower than those in other countries, and until 2013, the total number of PhDs in most of the selected countries (except Japan) had increased significantly. This indicates that since 2007, a PhD degree has remained difficult to obtain in Japan. However, although the number of $\mathrm{PhDs}$ in education research is the lowest among all fields, it shows a growing trend among all the selected countries. Compared with other selected countries, the proportion of PhDs in Japan is clearly the lowest, and has been declining in recent years; however, the imbalance between the supply and demand of graduating $\mathrm{PhD}$ students ("postdoctoral issues") still became the focus of reform policies. Furthermore, postdoctoral issues have been highlighted in the media as "invisible (employment) refugees" or "highly educated working poor," similar to the problem of stray doctors in Taiwan.

Figure 4. Number of PhDs in Education Research in the Selected Countries

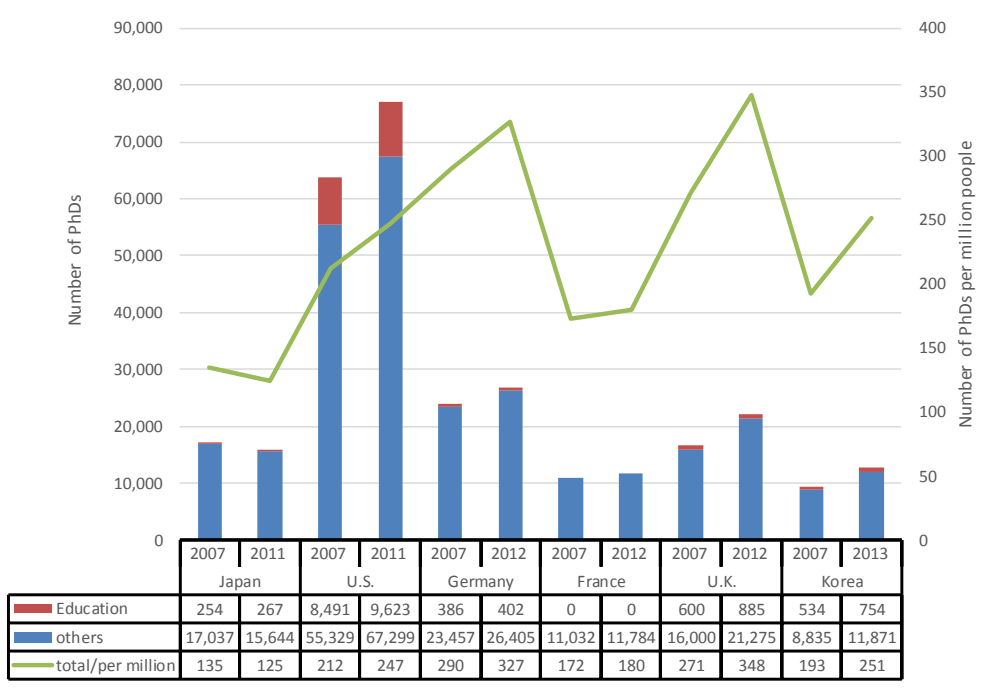

Source: Adapted by the author from MEXT and NISTEP (2015b, p. 147).

Hence, to support postdoctoral researchers, the JSPS offers three types of fellowships: postdoctoral fellow (PD), restart postdoctoral fellow (introduced in 2006, this fellowship is granted to outstanding young researchers suspending their research activities for childbirth and/or infant nursing purposes), and superlative postdoctoral fellow (this fellowship is granted to excellent researchers chosen from PD candidates). However, after 2014, the PD selection rate decreased significantly from 19.2 percent to 11.7 percent, and has remained at approximately 12 percent (12.5 percent in FY 2016) (JSPS 2016). This indicates that the application situation has become more competitive, and that only a few postdoctoral researchers can benefit from this support system.

Kitano (2015) conducted an international comparison survey in his book Post-doctor: Current Situation and Issues of Young Researchers Training, and indicated that the responsibility for solving and improving postdoctoral issues should not be attributed to the individual postdoctoral researcher. The Japanese government should be held accountable for the increase in postdoctoral researchers resulting from the policy of expanding graduate schools. However, in consideration of scientific development and the international situation, this policy is not unsound, because the increase in the number of postdoctoral researchers has not only contributed to strengthening basic Japanese technology research but also promoted the expansion and development of research (Kitano 2015). Therefore, to solve postdoctoral issues, universities and research 
agencies should cooperate with the government to promote the improvement of policies, in addition to the expansion of employment policy implementation by individual universities and research institutions.

According to Kitano's comparative analysis of survey results (from Japan, the United States, the United Kingdom, Germany, France, and mainland China) as well as the results of the interviews in the present study, the differences regarding the postdoctoral research systems between Japan and other countries can be summarized according to the following four points: First, the research environment in the United States is superior to that of Japan because of its more spacious laboratories, limited student guidance, and lower frequency of supervisors requiring postdoctoral researchers to perform menial tasks. Moreover, teacher-student relationships are strong in Japan; therefore, postdoctoral researchers may be asked to perform tasks other than research (Kitano 2015). The results of the interviews in this study (interviewees E, G, I, K, and N) suggested a similar opinion. Thus, postdoctoral researchers in the United States are more able to concentrate on research.

Second, Japan's style and treatment of employment are relatively insecure. In Japan, most positions for postdoctoral researchers are fixed term (three-to-five years) and lack comprehensive insurance coverage (i.e., health insurance, social insurance, and employment insurance). According to the results of the interviews in this study (interviewees E, G, I, K, and N), the unstable and transient nature of the fixed-term position has forced postdoctoral researchers to constantly worry about the next job and prepare for it, leading them avoid concentrating on research. In addition, they must even assume unpaid or part-time employment (e.g., hourly wage positions) (Kitano 2015). Specifically, up to 30.2 percent (2006) of postdoctoral researchers in the humanities and social sciences (other fields are less than 8 percent) are engaged in work without an employment relationship. Conversely, unpaid or part-time postdoctoral research positions do not exist in the United States, Germany, or France. Kitano (2015) stressed that in the United States, the NSF as well as universities have clear requirements for postdoctoral research employment, which concern the contents of the employment contract, insurance, accommodations, and even career education. Kitano also indicated that in Japan, the basic human rights of postdoctoral researchers, particularly regarding insurance, should be seriously considered.

Third, the proportion of postdoctoral researchers in business enterprises is far lower in Japan than in the United States, Germany, or France. From 2002 to 2014, the proportion of doctorate holders at universities and colleges gradually increased (57.1 percent in 2014), but a low proportion of approximately 4 percent remained in business enterprises (MEXT 2015). This suggests that in Japanese business enterprises, there is a shortage of positions in which postdoctoral researchers can utilize their capabilities and experience (Kitano 2015). Kitano (2015) indicated that in Japan, new specialized positions should be developed in government departments, research agencies, and even business enterprises, in response to the NSF suggesting "employment outside universities" and the French government recommending "the preparation of education for industry employment" in 2006.

Fourth, the age requirements in Japan are clear and strict regarding employment and applications for postdoctoral fellowships. Although lifelong learning policies have continually been promoted, and the age requirement of JSPS postdoctoral fellowships (under 34 years of age) was abolished in FY 2014, some tacit understandings remain, such as "after graduating, researchers should find full-time research positions before a certain age," and "young researchers are considered as being younger than a certain age." In other words, young researchers who are older than a certain age may experience difficulty finding full-time research positions. For example, the Japanese government's recommendation for such positions is 35 years of age. In addition, researchers who are older than a certain age cannot apply for any young researcher supporting grant programs. For example, the Grants-in-Aid for Young Scientists in KAKENHI requires applicants to be younger than 39 years. Hence, "aging postdoctoral researchers" (i.e., the proportion of postdoctoral researchers older than 35 years is increasing) are also considered a problem (Kitano 2015). Some interview comments from Japanese overseas postdoctoral researchers regarding reasons for overseas studies have included the following: "At this age, I have been unable to find research positions in Japan" (Kitano 2015). Additionally, the results of the surveys in the present study (respondent W) indicated a similar opinion.

Since the government has encouraged the re-education of public researchers, I want the government to abolish age restrictions for research grant applications. Although the age limit has been removed from the application conditions of JSPS fellowships, the date of birth must still be filled out on the application forms. So it does not make sense." "In Japanese society, the so-called 'young' researcher generally refers to age. (Respondent W, 2015)

In other words, in Japan, regardless of whether the age requirements are clearly defined, tacit understandings of age have actually increased pressure on postdoctoral researchers, which may result in their experiencing difficulty with research (i.e., grant applications) and employment. 
In summary, these four points regarding differences in the postdoctoral research system can explain why the proportion of $\mathrm{PhDs}$ in Japan is clearly the lowest, and why postdoctoral issues have been relatively serious in recent years. It is mainly because the Japanese government did not account for the supply (the number of doctorate holders) and demand (the number of full-time positions in academia or business enterprises) in the actual labor market while promoting the expansion of graduate schools. In addition, compared with the United States, which has a postdoctoral research system with a long history (established in 1870), and Germany and France, which both have a long history of close cooperation between graduate schools and business enterprises, Japan lacks a historical foundation for its postdoctoral researcher system (established in 1985); therefore, Japan's postdoctoral research employment system (i.e., training environment, treatment, grants, and the manner of cooperation between graduate schools and business enterprises) still requires improvement.

\section{Analysis and Discussion}

Through the preceding overview of the two periods of cultivation of next-generation academics in the main objective countries, the identified international trends can be summarized as follows.

\section{Trend 1: Fostering Membership of Graduate Students}

In both Japan and the United Kingdom, people have increasingly recognized the importance of fostering the coordination of membership through teamwork in the graduate school period in the past six years, particularly regarding doctoral programs. Additionally, current cultivation of next-generation academics should help young researchers become multitalented, so that they can be entrepreneurial, interdisciplinary, and skilled in negotiation and project management as well as in the traditional protocols of a discipline. In general, compared with science and engineering research, research projects in education are mostly individual based rather than team based. Hence, in addition to the limited funding that is typically granted for an education research project, an individual-based project may yield limited research results. For example, in Taiwan, the amount of funding granted for an overseas education research project (individual-based) regarding foreign educational systems is limited, and the number of times funding can be granted for overseas fieldwork has been limited as well. Therefore, researchers can conduct overseas fieldwork only once a year. Because of limited funding and travel restrictions, researchers must travel abroad alone to complete their research projects (i.e., interviews, surveys, document and data collection). In general, funds are not granted for hiring graduate students or research assistants for overseas fieldwork.
Therefore, to foster graduate student membership in education research, which is the typical research style of science and engineering, establishment of research teams should be encouraged; a research team grant support system is also necessary. A research team's project may be able not only to obtain more funding but also to attract more graduate students to the project through employment opportunities. Additionally, according to the EHEA's concept of mobility and reform strategies for enhancing graduate employability, cross-country and inter-institutional research teams are worth promoting. The results of the surveys in this study revealed a similar opinion: "I think it is more helpful for my research to join a research group outside the university" (Respondent U, 2015).

\section{Trend 2: Focusing on the Employment of Postdoctoral Researchers}

To solve the aforementioned issues, the Japanese government has actively promoted various policies and strategies concerning the cultivation of postdoctoral researchers. Programs include Grants-inAid for Young Scientists (start-up), the Tenure-Track System Promotion Program, and the Young Researcher Overseas Visits Program for Vitalizing Brain Circulation. However, according to the comparative analysis by Kitano (2015) and the results of the interviews in the present study, employment opportunities outside universities, such as those in business enterprises and government agencies, remain limited.

The main reason lies in the differences in the nature of doctoral programs between Japan and Germany or France. Because the nature of doctoral programs in Japan is research oriented, doctorate holders are often stereotyped as "professional idiots" in business enterprises (Kitano 2015). Granrath, who has been the supervisory innovation coordinator of the Japanese National Institute for Advanced Industrial Science and Technology since 2014, and who graduated from the University of Karlsruhe in Germany and earned his doctorate at the University of St. Gallen in Switzerland, has also indicated that compared with Germany, "PhD programs are extremely structured" in Japan; specifically, they are thesis oriented, but lack training in the context of internships, foreign language skills, and overseas study experience (Granrath 2015). Hence, in Germany, where the nature of doctoral programs is employment oriented, a doctorate is an additional qualification and may lead to an increase in salary (Granrath 2015). Conversely, having a doctorate at a Japanese business enterprise may become an obstacle and may not lead to an increase in salary.

Additionally, Åkerlind (2005) conducted an international comparison (i.e., the United States, Canada, the United Kingdom, and Australia) and a survey of postdoctoral research positions through an interview-based investigation of the views of both postdoctoral 
researchers (all interviewees were from research-intensive universities in Australia) and postdoctoral supervisors regarding the nature of postdoctoral research positions and the career development support provided for these positions. Åkerlind suggested that "as long as postdocs are trained by academic researchers in an academic research setting, it seems inevitable that they will continue to aspire to academic and research-only careers." In other words, postdoctoral researchers may have no intention of working outside universities from the outset.

However, academic supervisors (i.e., those with academic expertise and no work experience at business enterprises) are generally unlikely to be expected to provide guidance in meeting the diverse needs of business enterprises with all their doctoral students. Thus, according to the preceding analysis of difficulties in implementing the Japanese industrial $\mathrm{PhD}$, the fundamental solution for the limited employment of postdoctoral researchers in education research involves improving the stability (i.e., reducing mobility) and treatment (e.g., health insurance) of employment in academia, rather than expanding employment in business enterprises (i.e., employment preparation education.) Specifically, because of their age, postdoctoral researchers are typically faced with career planning and decisions (e.g., marriage, having children); therefore, a stable personal economic situation (e.g., financial support systems) is urgently required (respondent $\mathrm{X}, 2015$ ).

Moreover, research requires long-term investments of time and effort, particularly for novice researchers. Over a short period (i.e., less than three years), the results of a single study are difficult to present and their research value may not be properly evaluated. Hence, from the perspective of national scientific development and cultivation of next-generation academics, the negative effect (e.g., postdoctoral researchers cannot concentrate on studies because they must often worry about finding and preparing for the next job) of the short-term employment system is greater than its positive effect (e.g., increasing competitiveness and mobility). Although many types of occupations are also faced with changes and uncertain futures because of the volatile global economic situation, postdoctoral careers remain distinct and such employment issues should be discussed individually.

To improve the stability and treatment of postdoctoral research employment in academia, Kitano (2015) suggested that the National Postdoctoral Association of the United States is an excellent reference for Japan regarding the development of a "transverse network" between universities and research institutions for the promotion of national postdoctoral support projects. Additionally, according to the preceding analysis of the establishment of research teams in education research, the projects of cross-country or inter-institutional research teams benefit from increasing the employment opportunities for postdoctoral researchers.

\section{Trend 3: Encouraging International Experience of Young Researchers}

According to the preceding analysis of the concept of mobility in higher education, whereas students have been encouraged to join the international movement strategy developed by European or American universities for many years, Japanese universities, with the stereotype of having relatively exclusive reputations, have increasingly recognized the importance of internationalization in the graduate school period for the cultivation of next-generation academics in the past seven years. Thus, at the Tohoku University Graduate School of Education, the Asia Joint Degree Project, which was adapted from European models, has attempted to provide opportunities for graduate students to study abroad and achieve a joint degree through international cooperation with universities in Asian countries since 2011 (e.g., Japan, Taiwan, mainland China, and South Korea). Moreover, one of the aims of its Asia Education Leader Course is "developing professional (e.g., studying East Asian languages) researchers in education who can address the issues and challenges faced by Asian societies" (Tohoku University Graduate School of Education 2016b). Several themes, such as "The possibility of a new human resource development through international joint degree [sic]," "Internalization of higher education," and "World-system theory and international student mobility," have been discussed at international symposiums. Although such issues (e.g., language and essay writing guidance) are not easy to resolve, the vision of Asian academic cooperation, as in the Bologna Process or EHEA in European countries, is meaningful.

However, whereas the results of the survey in this study show that 50 percent of doctoral students emphasize their need to acquire English academic writing ability (e.g., subsidies for correction of English abstracts by native speakers), some students believe that the global talent cultivation strategy has increased pressure on young researchers because they are pressed to join international events (respondent V 2015). In other words, with the internationalization of higher education, some graduate students in non-English-speaking countries may be pressed to acquire foreign language skills (especially English). To avoid placing additional burdens on students, adopting a more gradual approach in promoting the strategies of internationalization in graduate school education is necessary; graduate school is a fundamental period for the cultivation of next-generation academics.

\section{Conclusion}

Through the preceding analysis of three international trends, the importance of Bourdieu's (1986) forms of capital theory (i.e., cultural capital, social capital, and economic capital) is verified. Ac- 
cording to his theory, in the cultivation of next-generation academics in education research, cultural capital may include basic research ability and language skills; economic capital may refer to research funding and equipment; and social capital may refer to academic networks and personal connections. Because capital has characteristics of accumulation and institutionalization, it "takes time to accumulate" "personally by the investor" (Bourdieu 1986) and its effect does not become evident within a short period. In addition, because of the convertibility of the three types of capital, they tend to influence one another. Thus, to address current issues regarding the cultivation of next-generation academics in education research, these three aspects require simultaneous attention; a long-term system for implementing cultivation and employment should be considered.

First, cultural capital (closely related to cultivating institutions such as universities) is a main factor that determines the level of a researcher's quality, and it also affects whether the researcher can obtain social capital or economic capital, such as JSPS fellowships and the NSF's IGERT. Hence, increasing cultural capital (i.e., "habitus") facilitates improving researchers' strengths and competitiveness. According to the results of interviews and surveys of young researchers in this study, 80 percent of incumbents (including postdoctoral researchers) stated that they definitely benefit from learning research methodologies (i.e., quantitative and qualitative research) during school; 90 percent of graduate students stressed their needs for learning research methodologies. Moreover, with the internationalization of higher education, the "linguistic capital" of foreign languages has become increasingly critical. Thus, to mitigate the effects of students' social class backgrounds (i.e., "the reproduction of the social structure"), enhancing foreign language skills and encouraging the international experience of young researchers through grants in the nurturing system is necessary.

Second, social capital may often affect the accumulation of cultural capital. Consequently, fostering membership and the interdisciplinary skills (according to the concept of mobility) of young researchers enhances their social capital; thus, both their cultural (i.e., academic achievements) and economic capital (i.e., grants) may be increased simultaneously. As mentioned, professional educational societies have played this type of influential role in the cultivation of next-generation academics. Additionally, the number of various activities and seminars for young researchers, such as the JSES's Young Researchers Exchange Meeting, is expected to increase.

Third, economic capital is generally considered the most valuable factor according to the interviews and surveys in this study. For example, most graduate students expressed that part-time employment interferes with their research time; therefore, financial support, such as that for covering cost-of-living expenses, is necessary (respondent V, 2015). Additionally, because of the severe shortage in research positions resulting from low birth rates and economic recession, economic capital has become increasingly critical for postdoctoral researchers. Thus, as mentioned, in the main objective countries, public and private universities as well as official or nongovernmental education research organizations continue their efforts to focus on the employment of postdoctoral researchers and improve their financial support systems. Consequently, researchers who receive grants, such as JSPS fellowships in Japan, the NSF's IGERT and SciSIP-DDRIGs in the United States, and DTCs in the United Kingdom, have relatively favorable academic performance and prospects to attain employment. Additionally, economic capital (grants) facilitates the accumulation of social capital (i.e., researchers have sufficient funds to participate in academic activities). Specifically, with the development of network technology and social media, having economic capital may be highly advantageous, rather than having cultural or social capital. In other words, today's economic capital was confirmed to be crucial in the cultivation of nextgeneration academics in education research. Furthermore, the relationship among the three types of capital shows a clear positive cycle.

In brief, from a macroscopic viewpoint of international comparison, assessing a single country's system for cultivating next-generation academics in education research and proposing directions for improvement may be possible according to the adequacy of cultural, social, and economic capital. However, as Hashimoto (2013) indicated, "whether a researcher can be successful in research and obtaining employment, including the quality of the individual, has been considered very uncertain. In addition, graduate student life has been positioned as an activity related to academia, rather than an activity related to standardized university education; therefore, its diversities have occurred because of not being under the supervision of the university." Moreover, because the career path to obtaining tenure is uncertain, considering each application of Bourdieu's forms of capital theory on a case-by-case basis is necessary. Hence, in addition to the macroscopic analysis of the systems, in the future, microscopic analysis of the cultivating process (individual level) within universities should be continued and stressed.

Furthermore, as a respondent in the survey in this study indicated, "rather than cultivation itself, the amount of supply and demand should be adjusted" (respondent U, 2015); the serious imbalance between supply and demand in the employment market, which resulted from the overexpansion of higher education, should be resolved immediately. Otherwise, postdoctoral researchers as well as graduate students may become more negative during study or research because of anxiety regarding their future careers. In other words, the fundamental problem is that if employment cannot be provided properly, regardless of training quality or the amount of funding, postdoctoral researchers are likely to lose their motivation. 
On the basis of the results of the comparative research on the main objective countries, this paper presents the following conclusions and offers recommendations for future research. Although the results macroscopically show global trends and enhance the understanding of current development in the cultivation of next-generation academics, a micro-level analysis of the implementation of policies and strategies as well as the individual behavior of stakeholders was essential to make this study complete. Furthermore, the cultivation of next-generation academics is a continuous process, and thus, exploration of the previous stage of undergraduate study and the following stage of new faculty membership is necessary. Specifically, according to the initial results of the interviews, the Japanese government issued no specific instructions or policies regarding the cultivation of undergraduate students. This approach is different from the research trends of the United States and Europe. Moreover, the following stage of new faculty membership is expected to be a productive and innovative period for research. Therefore, for the national development of and competition in scientific research, an international comparison of the support systems regarding this stage is also necessary. In summary, this study suggests conducting further comparative research on the cultivation of nextgeneration academics in education research by using a comprehensive framework comprising four periods: undergraduate study, graduate school, postdoctoral research, and new faculty membership. Furthermore, this study suggests that such future research will be a valuable reference for Taiwan, Japan, and other countries.

\section{Notes}

1. This study is part of a research project financed by the Ministry of Science and Technology (MOST) in Taiwan entitled "An International Comparison on the Cultivation of Next-Generation Academics in Universities and Research Agencies, with a View to Improve Education Research Mechanisms in Taiwan."

2. Two methods are used for counting the number of researchers: counting the actual number (HC: head count) and determining the degree of engagement in research (FTE: full-time equivalent). Because the number of researchers is counted on the basis of the FTE in the selected countries, the FTE should be used when comparing Japan with other countries (MEXT and NISTEP 2015a).

\section{References}

Åkerlind, Gerlese S. 2005. "Postdoctoral Researchers: Roles, Functions and Career Prospects." Higher Education Research \& Development 24: 21-40.

Altbach, Philip G., and Jamil Salmi, eds. 2011. The Road to Academic Excellence: The Making of World-Class Research Universities. Washington, DC: The World Bank.

Ateş, Gülay, Karoline Holländer, Nadia Koltcheva, Snežana Krstić, and Filomena Parada. 2011. Eurodoc Survey I: The First Eurodoc Survey on Doctoral Candidates in Twelve European Countries. Belgium: Eurodoc.

Bourdieu, Pierre. 1986. "The Forms of Capital.” In Handbook of Theory and Research for the Sociology of Education, edited by J. G. Richardson (pp. 241-258). New York: Greenwood Press.

Carney, Jennifer, Alina Martinez, John Dreier, Kristen Neishi, and Amanda Parsad. 2011. Evaluation of the National Science Foundation's Integrative Graduate Education and Research Traineeship Program (IGERT): Follow-up Study of IGERT Graduates (Final Report). Arlington, VA: National Science Foundation.

Economic and Social Research Council (ESRC). 2016a. Doctoral Training Centres. Available online at: http://www.esrc.ac.uk/skills-and-careers/studentships/doctoraltraining-centres/; accessed on 15 February 2017.

ESRC. 2016b. Distribution of ESRC Studentships. Available online at: http://www.esrc.ac.uk/skills-and-careers/studentships/doctoral-training-centres/distribution-of-esrc-studentships/; accessed on 15 February 2017.

European Council of Doctoral Candidates and Junior Researchers (Eurodoc). 2016a. About Eurodoc. Available online at: http://eurodoc.net/sample-page; accessed on 15 February 2017.

Eurodoc. 2016b. Eurodoc Survey I: The First Eurodoc Survey on Doctoral Candidates in Twelve European Countries. Available online at: http://eurodoc.net/projects/completed-projects/eurodoc-survey-i; accessed on 15 February 2017.

European Higher Education Area (EHEA). 2012. Mobility Strategy 2020 for the European Higher Education Area. Available online at: http://www.ehea.info; accessed on 15 February 2017.

EHEA. 2015. Yerevan Communiqué. Available online at: http://www.ehea.info; accessed on 15 February 2017.

Granrath, Lorenz. 2015. Training System of Doctorates and Their Utilization in German Society. From the Experience as the Representative in Japan of the Fraunhofer. Available online at: http://data.nistep.go.jp/dspace/handle/11035/3064; accessed on 15 February 2017.

Hashimoto, Koichi, ed. 2013. Comprehensive Study on the Construction of the Innovation of Education Program and a New Human Resources Training Model in the Doctoral Program of 
the Humanities and Social Sciences Graduate School. Tokyo: University of Tokyo's Graduate School of Education. (in Japanese)

Hirota, Teruyuki, ed. 2012. Research Report: Survey of the Research Support Needs of Young Members, Graduate Student Members and Overseas Student Members. Tokyo: Japan Society for Educational Sociology Planning Department. (in Japanese)

International Consortium of Research Staff Associations (ICoRSA). 2016. ICoRSA. Available online at: http://icorsa.org; accessed on 15 February 2017.

Japan Science and Technology Policy Seminar Executive Committee. 2010. The Report of "Recommendations for the Resolution of Issues Concerning Young Researchers (Post-docs, etc.)." Available online at: http://kokkororen.com; accessed on 1 December 2016. (in Japanese)

Japan Society for the Promotion of Science (JSPS). 2014. Survey Results of the Employment Situations of the JSPS Fellows (Doctoral Program). Available online at: https://www.jsps.go.jp; accessed on 15 February 2017. (in Japanese)

JSPS. 2016. Outline of Grants-in-Aid for Scientific Research (KAKENHI). Available online at: http://www.jsps.go.jp/english/egrants/index.html; accessed on 15 February 2017.

Japan Society of Educational Sociology (JSES). 2013. JSES Young Researchers Seminar was Held for the First Time. Available online at: http://www.gakkai.ne.jp/jses/2013/03/29124234.php; accessed on 15 February 2017. (in Japanese)

JSES. 2015. Program. Available online at: https://www.komazawau.ac.jp/society/jses2015/program.html; accessed on 15 February 2017. (in Japanese)

Kitano, Akio. 2015. Post-doctor: Current Situation and Issues of Young Researchers Training. Tokyo, Japan: Toshindo. (in Japanese)

L'Association nationale de la recherche et de la technologie (ANRT). 2016a. CIFRE flyer: Doctoral fellowships program in France for foreign students. Available online at: http://www.anrt.asso.fr/fr/espace_cifre/mode_emploi.jsp?p=40\#04; accessed on 15 February 2017.

ANRT. 2016b. Les dispositifs Cifre: Dopez vos performances avec un doctorant. Available online at: http://www.anrt.asso.fr/fr/espace cifre/ac-

cueil.jsp?p=1\#.Vr2EV 196Uk; accessed on 15 February 2017. (in French)

Lee, Alison, and David Boud. 2009. "Producing Researchers: The Changing Role of the Doctorate." In Academic Research and Researchers, edited by A. Brew and L. Lucas (pp. 96-108). Buckingham, UK: Society for Research in Higher Education, Open University.
Liu, Yu-Fei. 2015. "Educational Research Organizations, Research Policies, and the Construction of Quality-Standards: The Relationship between Research and Practices in Japan." Journal of Comparative Education 78: 97-136.

McCarthy, Maureen Terese. 2014. "Federal Funding Sources for Interdisciplinary Graduate Training in the U.S." Paper Presented at Eighth Annual Strategic Leaders Global Summit: Interdisciplinary learning in graduate education and research, 9 September 2014.

Ministry of Education, Republic of China (Taiwan) (MOE Taiwan). 2001. White Paper on Higher Education. Taipei: MOE. (in Chinese)

Ministry of Education, Culture, Sports, Science and Technology (MEXT). 2011. The 4th Science and Technology Basic Plan. Tokyo: MEXT. (in Japanese)

MEXT. 2015. White Paper on Science and Technology 2015. Tokyo: MEXT. (in Japanese)

MEXT. 2016. School Basic Survey. Tokyo: MEXT. (in Japanese)

MEXT, and Technology \& National Institute of Science and Technology Policy (NISTEP). 2015a. Digest of Japanese Science and Technology Indicators 2015. Tokyo: MEXT and NISTEP.

MEXT, and NISTEP. (2015b). Statistics Collection 2015. Tokyo: MEXT and NISTEP. (in Japanese)

National Science Foundation (NSF). 2014. Proposal and Award Policies and Procedures Guide, December 2014 (Archived). Available online at: http://www.nsf.gov; accessed on 15 February 2017.

NSF. 2016a. About IGERT. Available online at: http://www.igert.org/public/about; accessed on 15 February 2017.

NSF. 2016b. Grant Proposal Guide, January 2016. Available online at: $\quad$ http://www.nsf.gov/publications/pub summ.jsp?ods key=gpg; accessed on 15 February 2017.

Organization for Creating Educational Research. 2016. Outline. Available online at: http://www.p.u-tokyo.ac.jp/kikou/outlinemain.html; accessed on 15 February 2017. (in Japanese)

Shibata, J. (2010). Policies of the Cultivation of Young Researchers in France, and Relative Suggestions for Japan. Tokyo, Japan: Japan Science and Technology Agency. (in Japanese)

University of Tokyo's Faculty of Education and Graduate School of Education. 2013. University of Tokyo's Faculty of Education and Graduate School of Education Annual Report 8 (20082012). Tokyo, University of Tokyo (in Japanese)

Tohoku University Graduate School of Education. 2016a. The Application of "Graduate Student Project-based Joint Research Grant." Available online at: 
http://www.sed.tohoku.ac.jp/lab/edunet/project/public/; $\quad$ accessed on 15 February 2017. (in Japanese)

Tohoku University Graduate School of Education. 2016b. Outline/Project Objective. Available online at: http://www.sed.tohoku.ac.jp/ ajp/about/index.html; accessed on 15 February 2017. (in Japanese) 